\title{
PENGAJARAN BAHASA INGGRIS TERHADAP SISWA TINGKAT DASAR DI RUMAH QUR'AN KHAIRUL UMMAH KECAMATAN GANDAPURA PROVINSI ACEH
}

\author{
Chalil As'ari ${ }^{1}$, Iswadi ${ }^{2}$, M. Afrizal ${ }^{3}$ \\ ${ }^{12}$ Dosen Program Studi Pendidikan Bahasa Inggris FKIP Universitas Almuslim \\ Email: chalil.asari@gmail.com, iswaditajmorawa@gmail.com, \\ afrizalumar1979@gmail.com
}

\begin{abstract}
ABSTRAK
Kegiatan Pengabdian kepada Masyarakat berupa pengajaran Bahasa Inggris kepada siswa tingkat dasar di Rumah Qur'an Khairul Ummah Kec. Gandapura Kab. Bireuen Provinsi Aceh bertujuan untuk: 1) meningkatkan kualitas pembelajaran Bahasa Inggris; dan 2) meningkatkan motivasi siswa tingkat dasar dalam mempelajari Bahasa Inggris. Pelaksanaan kegiatan pengajaran Bahasa Inggris kepada siswa tingkat dasar ini dilakukan menggunakan metode pembelajaran Student Centered Learning (SCL). Metode ini pada penerapannya melibatkan siswa secara aktif dalam proses pembelajaran, sehingga siswa lebih aktif mencari dan mempraktekkan kosa kata Bahasa Inggris yang diajarkan guru. Berdasarkan hasil pelaksanaan kegiatan PKM ini disimpulkan bahwa pelaksanaan pengajaran Bahasa Inggris kepada siswa tingkat dasar mendapat respon positif. Selain itu, siswa juga terlihat antusias dalam belajar Bahasa Inggis. Oleh karena itu, penggunaan metode SCL sangat diperlukan dalam kegiatan pengajaran Bahasa Inggris kepada siswa tingkat dasar. Adapun hasil pelatihan menunjukkan adanya peningkatan kualitas pembelajaran dan peningkatan motivasi siswa pada proses pembelajaran menggunakan metode SCL. Oleh karena itu, kegiatan PKM ini diharapkan menjadi kegiatan PKM yang berkelanjutan.
\end{abstract}

Kata Kunci: bahasa inggris, pengajaran, siswa tingkat dasar

\begin{abstract}
This activity of community service is in the form of teaching english toward the elementary students at the Rumah Qur'an Khairul Ummah Gandapura District Bireuen Regency Aceh Province. This activity aims to: 1) improve the quality of english learning, and 2) increase the motivation of elementary students in learning english. The implementation of english activities for elementary students was carried out using the Student-Centered Learning (SCL) method. In its implementation, this method involved students actively in the learning process so that students were more active in finding and practicing English words taught by the teacher. Based on the implementation results of the community service activity, it can be concluded that the implementation of teaching english toward the elementary students had a positive response. In addition, the students also seemed very enthusiastic in learning english. Therefore, the use of the SCL method was indispensable in teaching english toward the elementary students. The results showed that there was improvement in the quality of learning and the improvement of the motivation in the learning process using this SCL method. Therefore, this community service activity is expected to be a sustainable community service.
\end{abstract}

Key Words : elementary students, english, teaching 


\section{PENDAHULUAN}

Pengajaran Bahasa Inggris pada tingkat dasar bertujuan untuk memperkenalkan kepada siswa secara lebih dini bahwa ada bahasa lain selain Bahasa Indonesia yang merupakan bahasa nasional, yang perlu dipelajari untuk mengembangkan wawasan dan keilmuan. Selain itu, Bahasa Inggris juga digunakan sebagai alat untuk berkomunikasi dengan penutur bahasa aslinya dan bahasa pengantar pada universitas di negara-negara maju.

Kondisi pengajaran Bahasa Inggris tingkat dasar di Indonesia, terlihat masih banyak kekeliruan, bahkan banyak dijumpai pengajaran Bahasa Inggris memberikan banyak tugas yang tidak sesuai untuk siswa, seperti meminta siswa menerjemahkan kalimat yang sulit, menulis pola dan tata bahasa yang rumit dan kompleks, sehingga membuat semangat belajar siswa menurun. Namun, pengajaran Bahasa Inggris di tingkat dasar seharusnya mengajarkan siswa tentang kosakata dan kalimat sederhana sesuai dunia, konteks dan kebutuhannya melalui pola mengajar dan belajar yang menyenangkan, sambil bermain, menggambar, menyanyi dan bercerita atau mengekspresikan dirinya.

Selain itu, hal yang menghambat tercapainya tujuan pengajaran Bahasa Inggris di tingkat dasar adalah penunjukkan guru yang mengajar Bahasa Inggris oleh kepala sekolah bukanlah guru Bahasa Inggris. Guru sebagai pendidik memiliki peran yang sangat besar dalam pengajaran Bahasa Inggris pada Anak Usia Dini (english for young learners). Selain memahami metode dan pendekatan, guru harus memiliki pemahaman yang mendasar tentang perkembangan diri siswa, terutama dalam hubungannya dengan proses pembelajaran Bahasa Inggris agar tujuan pembelajaran tercapai sesuai harapan.

Aspek-aspek yang perlu diperhatikan guru dalam pembelajaran Bahasa Inggris di tingkat dasar, yaitu karakteristik siswa, tujuan pembelajaran dan lingkungan belajar. Pada pembelajaran Bahasa Inggris, proses pembelajaran anak berbeda dengan orang dewasa. Bahkan, ada yang berasumsi bahwa anak-anak lebih cepat memahami apa yang dipelajarinya dan mudah menangkap bahasa baru dari pada orang dewasa. Sehingga, jika anak belajar Bahasa Inggris lebih awal, maka akan lebih cepat menguasai bahasa target. Lalu, siswa akan berhasil mempelajari Bahasa Inggris jika memiliki tujuan mempelajarinya. Aspek ini berpengaruh pada keberhasilan belajar Bahasa Inggris siswa. 
Keinginan untuk berbahasa Inggris menjadi motivasi belajar Bahasa Inggris, sehingga siswa belajar dan memperaktekkan Bahasa Inggris, baik sendiri, bersama kawan atau guru. Aspek lingkungan sekitar juga berpengaruh pada pembelajaran Bahasa Inggris. Misalnya, jika ada teman yang mengganggu belajar atau mengajak bermain, maka siswa tidak mau belajar dan akan bermain bersama temannya. Oleh karena itu, guru harus menggunakan metode yang tepat untuk mengajarkan Bahasa Inggris kepada siswa SD agar pengajaran Bahasa Inggris berjalan efektif. Selain itu, guru harus menyiapkan bahan ajar yang menarik, teknik mengajar yang menyenangkan dan lainnya.

Pengajaran Bahasa Inggris pada siswa tingkat dasar membutuhkan keterampilan dan dedikasi pengajaran. Selain itu, guru Bahasa Inggris harus memiliki pemahaman yang baik tentang bagaimana siswa berpikir dan beroperasi. Hal ini berfungsi sebagai fondasi dalam pengajaran Bahasa Inggris kepada siswa tingkat dasar. Bahasa Inggris pada tingkat sekolah dasar diajarkan sebagai konten lokal untuk melayani kebutuhan masyarakat setempat. Pada level ini, siswa belajar Bahasa Inggris untuk pertama kalinya, sehingga siswa hanya belajar hal sederhana, seperti kosa kata, tata bahasa, dan lainnya. Tujuannya untuk membekali siswa kemampuan mendengarkan, berbicara, membaca dan menulis sederhana materi dalam Bahasa Inggris dengan menekankan pada keterampilan komunikatif dalam Bahasa Indonesia sejumlah topik yang relevan dengan kebutuhan lokal komunitas, seperti, pariwisata, industri, seni, dan lainnya.

Bahasa Inggris memiliki hubungan erat dengan resor pariwisata. Bireuen merupakan salah satu kabupaten di Provinsi Aceh yang memiliki banyak tempat wisata, seperti Pemandian Bate Iliek, Krueng Simpo, Pantai Kuala Jangka, Pantai Kuala Raja, Pantai Ujong Seukee, Air Terjun Ceuraceu, Pantai Peuneulet Baroh, Air Terjun Samalanga, Pantai Calok, Air Terjun Le Rhop, Air Terjun Piramida, dan lainnya. Hal ini memiliki peluang untuk mengundang orang asing datang ke Bireuen. Sehingga, masyarakat harus menyadari bahwa kondisi ini dapat memperoleh keuntungan dan menambah penghasilan, yaitu dengan menguasai Bahasa Inggris yang baik dan dapat berkomunikasi dengan orang asing secara komunikatif. Hal ini dikarenakan orang asing yang datang ke Indonesia berbahasa Inggris. Jadi, akan lebih baik dan menjadi kewajiban masyarakat di sekitar resor pariwisata untuk belajar Bahasa Inggris. 
Menguasai Bahasa Inggris merupakan salah satu cara untuk mendapatkan ilmu pengetahuan yang ada di dunia. Ada banyak buku yang ditulis menggunakan Bahasa Inggris, bahkan ada banyak berita dunia yang diberitakan dalam Bahasa Inggris, baik secara lisan seperti di televisi dan youtube maupun secara tulisan di surat kabar dan majalah. Maka, untuk menciptakan masyarakat yang dapat berbahasa Inggris, haruslah mempelajarinya dari tingkat dasar. Sehingga, guru harus mengajarkan siswa SD dengan benar, agar siswa dapat menikmati pembelajaran dengan baik dan berjalan lancar. Namun, kenyataannya masih banyak guru yang tidak dapat mengajar dan memotivasi siswa SD secara intensif. Padahal, adanya motivasi dari guru, dapat meningkatkan minat siswa untuk belajar Bahasa Inggris. Selain itu, guru harus menciptakan teknik alternatif untuk mengajar siswa SD dan membuatnya tertarik untuk belajar. Maka, kegiatan Pengabdian kepada Masyarakat ini dilaksanakan secara berkelanjutan dengan judul "Pengajaran Bahasa Inggris kepada Siswa Tingkat Dasar". Pelatihan ini dilakukan melalui lembaga pendidikan formal maupun nonformal, seperti telah diimplementasikan pada Rumah Qur'an Khairul Ummah Kec. Gandapura Kab. Bireuen.

\section{METODE PELAKSANAAN}

Pelaksanaan kegiatan PKM berupa pengajaran Bahasa Inggris kepada siswa tingkat dasar ini difasilitasi oleh dosen dari Prodi. Pendidikan Bahasa Inggris FKIP Universitas Almuslim, yaitu Chalil As'ari, S.Pd.I., M.Pd., Drs. Iswadi, M.Hum., dan M. Afrizal, M.Pd. Kegiatan ini didukung oleh Prodi. Pendidikan Bahasa Inggris FKIP Universitas Almuslim. Kegiatan PKM ini dilaksanakan dengan metode Student Centered Learning (SCL), yaitu metode belajar yang berpusat pada keaktifannya siswa. Guru berfungsi sebagai pengarah, sedangkan siswa aktif mencari dan mempelajari apa yang diajarkan guru. Untuk itu diperlukan metode pengajaran Bahasa Inggris yang relevan dengan materi pembelajaran maupun situasi dan kondisi siswa. Selanjutnya, situasi dan kondisi yang menyenangkan bagi siswa dalam pembelajaran dapat meningkatkan kualitas pembelajaran sesuai dengan target pencapaian akhir yang diinginkan. Adapun hasil dari kegiatan PKM ini dideskripsikan secara kualitatif dalam artikel pengabdian masyarakat untuk dipublikasikan pada jurnal pengabdian masyarakat baik cetak maupun online. 


\section{HASIL DAN PEMBAHASAN}

Pelaksanaan kegiatan Pengabdian kepada Masyarakat di Rumah Qur'an Kharul Ummah Kec. Gandapura dilaksanakan oleh dosen Prodi. Pendidikan Bahasa Inggris, yaitu Chalil As'ari, S.Pd.I., M.Pd., Drs. Iswadi, M.Hum., dan M. Afrizal, M.Pd. Kegiatan ini dilaksanakan selama 3 hari, mulai dari tanggal 8 s.d 10 Maret 2021. Pada hari pertama, tanggal 8 Maret 2021, M. Afrizal, M.Pd. melaksanakan tugasnya yaitu mengajar di kelas dengan materi alphabet menggunakan metode Students Centered Learning (SCL) dengan tujuan menciptakan siswa aktif, sedangkan guru berfungsi sebagai fasilitator. Setelah memperkenalkan huruf abjad dari A s.d Z dengan metode drill seperti “/bi/ okay my students, repeat after me, /bi/again/bi/", media kartu bertuliskan huruf abjad digunakan untuk mengajar dalam bentuk kelompok yang berjumlah empat kelompok. Tiga kelompok terdiri atas 4 siswa dan satu kelompok terdiri atas 5 siswa. Setelah siswa mempraktikan huruf-huruf yang ada di kartu dalam kelompok masing-masing sesuai arahan, siswa diajak bernyanyi lagu alphabet bersama-sama, sehingga suasana kelas fokus dengan suara Bahasa Inggris dari siswa. Lalu, diakhir pertemuan siswa ditunjuk satu persatu untuk mengeja namanya sendiri dengan ejaan Bahasa Inggris.

Pada hari kedua tanggal 9 Maret 2021, Chalil As'ari, S.Pd.I., M.Pd. melaksanakan tugasnya, yaitu mengajar dengan materi Parts of Body. Setelah memperkenalkan anggota tubuh, siswa diminta menyebut anggota tubuh yang ditunjuk. Guru menunjuk kepala, siswa menyebutkan "Head" okay Class, repeat after me, head,... head" very good. Lalu, siswa diminta bekerja berpasangan (work in pairs) dengan cara yang satu menunjuk anggota tubuh (menunjuk hidung) dan pasangannya menyebutkan (nose). Setelah itu, siswa diajak bernyanyi bersama lagu "Head Shoulders knees and toes". Lalu, diakhir pertemuan siswa diajak bermain game "Simon Says".

Pada hari ketiga tanggal 10 Maret 2021, Drs. Iswadi, M.Hum melaksanakan tugasnya, yaitu mengajar dengan materi Family Tree. Setelah memperkenalkan anggota keluarga yang ada pada diagram silsilah keluarga, siswa diminta menyebutkan anggota keluarga yang ditunjuk, seperti (ditunjuk ayah, siswa menyebut father) dan seterusnya. Lalu, siswa diminta memperkenalkan anggota keluarganya, seperti my name is Husain, my 
father is Ali, my mother is Fatimah, and my brother is Hasan. Selanjutnya, diakhir pertemuan, siswa diajak bernyanyi lagu "If you are happy, clap your hand".

Setelah kegiatan PKM berupa pengajaran Bahasa Inggris kepada siswa tingkat dasar yang dilaksanakan selama tiga hari di Rumah Qur'an Khairul Ummah, diperoleh hasil sangat memuaskan dan terlihat siswa mampu melafalkan alphabet dengan benar; mengeja namanya dengan Bahasa Inggris; menyebutkan anggota tubuh dengan Bahasa Inggris; menyebutkan anggota keluarga dengan Bahasa Inggris; siswa sangat antusias belajar Bahasa Inggris dengan adanya lagu dan game, siswa bersemangat untuk belajar. Adapun luaran yang dicapai dari hasil kegiatan PKM ini berupa publikasi pada jurnal Rambideun (Jurnal Pengabdian kepada Masyarakat ber ISSN, baik cetak maupun online) dan dipublikasikan pada web LPPM Universitas Almuslim.

\section{KESIMPULAN DAN SARAN}

Dari hasil implementasi kegiatan PKM berupa pengajaran Bahasa Inggris kepada siswa tingkat dasar yang telah dilaksanakan di Rumah Qur'an Khairul Ummah Kec. Gandapura Kab. Bireuen, disimpulkan bahwa: 1) kegiatan pengajaran Bahasa Inggris ini sangat dibutuhkan oleh masyarakat untuk meningkatkan kemampuan berbahasa Inggris dari dini pada era milenial sekarang, dikarenakan semakin dini anak belajar Bahasa Inggris, semakin mudah anak tersebut menguasai Bahasa Inggris; 2) kegiatan PKM ini memiliki daya tarik tersendiri bagi siswa karena menggunakan metode pengajaran yang tepat dan lagu serta game dalam penyampaian materi pembelajaran di kelas; dan 3) melalui kegiatan pengajaran ini, siswa terlihat lebih tertarik mengikuti pembelajaran.

Adapun saran yang dapat disampaikan setelah telaksananya kegiatan PKM ini adalah hendaknya kegiatan PKM berupa pengajaran Bahasa Inggris kepada siswa tingkat dasar dijadikan sebagai kegiatan yang berkesinambungan. Hal ini dikarenakan adanya peningkatan kemampuan berbahasa Inggris bagi siswa serta adanya peningkatan motivasi belajar Bahasa Inggris bagi siswa sejak dini. 


\section{UCAPAN TERIMA KASIH}

Terima kasih yang tidak terhingga diucapkan kepada ketua Yayasan Rumah Qur'an Khairul Ummah Kec. Gandapura Kab. Bireuen Provinsi Aceh yang telah membantu dan memfasilitasi kegiatan Pengabdian kepada Masyarakat (PKM) ini. Selanjutnya, ucapan terima kasih juga disampaikan kepada seluruh guru yang telah membantu kelancaran kegiatan PKM. Terakhir, tidak lupa diucapkan terima kasih kepada The Red Land Foundation yang telah memberikan dukungannya, baik moril maupun materil. Semoga kegiatan PKM ini akan berguna dan menjadi kegiatan yang berkesinambungan.

\section{REFERENSI}

Brown, H.D. 2007. Teaching by Principles: an Interactive Approach to Language Pedagogy, New York: Addison Wesley Longman, Inc.

Cameron, L. 2005. Teaching Language to Young Learners. Cambridge: Cambridge University Press.

Cremin, T. 2005. Teaching English Creatively (Learning to Teach in the Primary School Series). N.Y. Routledge.

Hadfield, J. and Hadfield, C. 2000. Simple Speaking Activities. Great Britain. Oxford University Press.

Phillips, D., Burwood, S. and Helen D. 2000. Projects with Young Learners. N.Y. Oxford University Press.

Scoot, W.A. and Ytreberg, L.H. 1991. Teaching English to Children. N.Y. Longman.

Wallace, M. J. 1991. Action Research for Language Teachers. Cambridge.Cambridge University Press. 